\title{
OUTSELVES Linked: Cultural Alienation in Literary Performance
}

\author{
M.Gewaily \\ Minia University, Egypt \\ E-mail: mahmohamedg@yahoo.com.au
}

Doi:10.7575/aiac.alls.v.5n.2p.142

Received: 01/03/2014

URL: http://dx.doi.org/10.7575/aiac.alls.v.5n.2p.142

Accepted: 09/04/2014

\begin{abstract}
This article is a study of the relationship between the self and its others. It aims to reconsider the two major principles of relevance and context to present a human relationship between the art of communicative performance and the art of cognitive competence throughout some mental representations in literary performances. The article here draws attention to the three main criteria of the discourse of a work of art: 'Make, Intend and Agree'. This set of three key terms is to be compared with the liberal art of writing in a random selection from the oeuvre of four different authors. The main question is: Is there unity in the writings of different writers? There will be reference to the selective works of a group of well-known writers: such as J.Swift, N.Mahfouz, N.Gordimer and L.Hughes. The article attempts to present how these four writers stress that the cultural alienation (betrayal) is generated by the mechanical execution of legislation, and then contrasts it with the contact (moral belonging) established in the intuitive understanding of right and wrong.
\end{abstract}

Keywords: Culture, alienation, translation, belonging and betrayal

\section{A Way of Seeing}

The three fundamental levels of a work of art, in Martin and Jacobus's book The Humanities through the Arts (5th ed, 1997: p. 19), are given: (A) that the work of art is "made" by an artist; (B) that it is "intended" to be a work of art by its creator; and (C) that pioneer critics and experts "agree" that it is a work of art. After much discussion the authors state that these three criteria are not to be determined, unfortunately. Nevertheless, it is debatable whether this remains true of all the three criteria of the comparative construal that Martin and Jacobus describe. The spectrum of this article is sweeping as it highlights three key terms (make, intend and agree); they sit in parallel lines to the three other terms I discussed elsewhere (translation, liberty, and art) (Gewaily 2013). That is, the article questions the possible making of translation adaptation; the possible intention of liberty as a course of action; and the agreement or disagreement of critics toward the political and verbal art of Césaire. It has been important to rethink the three dimensions of 'translation, liberty and art' in a comparative study of Césaire's play (AT) and Shakespeare's (TT) to provide an objective rereading of the two texts. This indicates how both the self (mastery) and the other (colonialism) may work, when placed in dialogic interface, and this can present a response to the challenges against the political and literary stance of Césaire then. Still, the three proposed terms are not without meaning. I shall undertake them next as they work as a catalyst to the development of the study. The focus here will be, not indiscriminately, on the roughly neglected 'content and style' debate in order to address the change of style as an "attitude." the following discussion of worlds on paper is an attempt to present a dialogic way of seeing in away to respond to the two first verbal action: the "making" of the work of art and the" intention" beyond it.

Before this article (Gewaily 2013) discusses Translation as Liberal Art in four main voices, the article Translation and the Metaphor of Relation *Gewaily, 2014) proposed to approach the relational view of these four voices to the view of the relationship of reflection, selection and deflection and how this triple play leads to the voice of coalition as a foundation to a developed way of looking at a literary work of art. I analyze the research on Bakhtin as a translationalist, concentrating on the role of earlier scholars interested in dialogism. In the second, "VOICES Selected" I will examine the position taken to specify the first two primary aspects of the linguistic and the cultural: the art of answerability as a liberal art along with its connective to the cultural aspect of (post-)colonialism. Although the relationship between dialogism and answerability has been paid considerable attention, relatively little attention has been paid to the relationship between answerability and (post-)colonialism. In this preparatory background, I show how the thought by Bakhtin and by others around him come together. This view of togetherness in view of the self and the other was applied in some detail through a comparison of the two plays (TT and AT), reflecting the other two semiotic and pragmatic aspects of the relationship between (the self and the other), between (the ST and the TT) through a discussion of the basic contents of certain contexts of situations to reflect shades of meaning between (the TT and the $\mathrm{AT})$.

In the present article, I turn back to the consideration of voices through a discussion of the self and the other from the two major principles of relevance and context. The goal of discussion is to determine how a parallel mix of the three criteria of the work of art along with the proposed three key terms can help determine how far the position taken by the author's presentation, regarding "Engaging the Mind's Eye", is worth consideration. This presentation requires to divide the study into three sections and a conclusion. Section 2 will shed a brief light on the finding of the term culture in cultural alienation. Section 3 will discuss the "making" of the past literature through a particular focus on Swift's literary masterpiece. Section 3 will discuss aspects from the works of the three renown writers, Mahfouz, Gordimer and 
Hughes, in two complementary subsections. Then, I will devote a final note to the whole position of the article I have taken.

\section{TRANSLATION User as Performance}

The term "culture" refers to the knowledge of the world that the members of a particular society share. It plays a crucial role in one's understanding of one's world and one must be familiar with it so that one can be familiar with others' behaviors and their attitudes, through "a set of semiotic systems, a set of systems of meaning, all of which interrelate" (Halliday, 1989: 4). In the view of Ong (1977: 10), the new studies involving the relation between the Occident (Europe and the Americas) and Central and West Africa "have been grouped around the dialectically related themes of change or alienation on the one hand and growth or integration on the other." Alienation generally means an estrangement from society, isolation, and powerlessness. There are two types of alienation: when the alien is a bit of rebel, very independently minded, or when he is a victim of corrupt social and political surroundings, one who lets himself be trampled upon without a fight.

One of many necessary elements of community, including a culture, is the real sense of cosmic order which is necessary to crown all aspects of life-personal and public with a degree of power. A way of looking at the core of the function of language in the establishment of communication between speech communities is to think of translation, as Baker (1992, p. 4) aptly puts it, as a "discipline which has to concern itself with how meaning is generated within and between various groups of people in various cultural settings." In other words, a central twentieth-century crisis is cultural alienation -- it widens the gap between tradition and modernity, the old and the new, throwing the individual into an abyss of self-apathy which in turn annuls one's duty of belonging to the motherland. Not only is modern man alienated from his own community, his family, and his past, but he is thus, inevitably deprived of the chance to know all that is required about himself, his raison d'être, and what he lives for. It is this lack of belonging which accounts for his own sense of being betrayed and consequently leads to an act of betrayal by him.

In this particular sense of culture, alienation, translation, and cultural alienation, it has been the aim of this article to see through the ways of presenting the meaning of cultural alienation across different literary texts in the attempt to understand how meaning, as Baker said, is "generated" with different people across different communities. In principle, this article pays attention to how the two types of political order and the moral order are interlocked, along with a representation of the lack of such order in a number of literary texts, as this particular focus on order will show the play of literary performances. Within a discussion of this view of order, a sample of political order will be given first (Jonathan Swift), and through that I will come to a discussion of the moral order which is focal to this article through a discussion of samples of writings by three international and pioneer writers (Jonathan Swift, Nadine Gordimer, Naguib Mahfouz and Langston Hughes).

\section{Making the Past: A Question of Perspective}

As a politician, Swift was only aware that "our duty, by becoming our interest, would take root in our natures, and mix with the very genius of our people." If anything, to be sure, foreign commentators were still more loudly impressed, Martin Price had arrived at a quite remarkable conclusion in his book To The Palace of Wisdom: "Swift's interest in politics and morality raises the larger issue of his cast of mind" (1984: 184). In Gulliver's Travels, Swift represents orders in conflict with one another at its best expression. Gulliver, the protagonist of this novel, is a traveler, who has been, at one time or another, physically, or mentally imprisoned. He has a set of four voyages to Lilliput, to Brobdingnag, to Laputa, and to Houyhnhnms, respectively. The Yahoos are allegorical representations of the ignorant, hungry, and subjugated Catholic peasantry of Ireland. There has been much disagreement over Swift's use of satirical allegory. One feature of Swift's use of language is that he can hide behind the façade of the language he chooses to employ and thereby say a great deal than would otherwise be permitted. Swifts tries to detach himself to achieve an objective criticism. This is achieved when he removes the action to a remote location as it is the case in Gulliver's voyages. For Price (1984: 197) Gulliver's Travels takes into consideration essential questions about:

the nature of politics, like the ideal reconciliation of duty and interest among the Houyhnhnms and the less perfect, but more humanly feasible, reconciliation in Brobdingnag. To these political orders are opposed such societies as that of the Lilliputians, which is elaborately administered disorder, the tyrannies of Laputa and Maldonada, and the savage democracy of theYahoos. Gulliver's Travels is a tribute to the mixed state in which order is reconciled with freedom and yet made stable. To achieve such an order, one must come to terms with the nature of power, and the most essential feature of power is its tendency to become absolute.

What does the practice of law in Lilliput mean? At the very beginning, the narrator in Swift's Gulliver's Travels (1974) is careful to "gratify the curious reader" with some general ideas. He discusses some laws and customs in this empire, which are so distinctive. These laws and customs are different from his own "dear country"(1976: 59). The first is about "Informers." Gulliver mentions that any crimes against the state is a punishable offense with "the utmost Severity": the accuser is committed to death when the accused is found innocent. The wish of the Emperor to conquer the world is opposed by Gulliver as a symbol of absolute weapon. It is the "spirit of opposition" that governs the world of Lilliput; there is also "a violent faction at home, and the danger of an Invasion by a most potent Enemy from abroad" (1976: 50). Among the events in this state are the appointment of ministers and the declaration of the clemency of the king. The judgment of the court is misleading and obfuscated. This is clear when Gulliver sets fire into the palace of the Empress; the court's accusation is not biased: "Whereas ... it is enacted that whoever shall make water within the precincts of the royal palace shall be liable to the pains and penalties of big treason..." (68). We see Gulliver's reactions are minimal because of a partial sense of gratitude, but later he reveals to the court of Brobdingnag the truth. This happens when he assimilates that power confers the sense of right. With the rejection of his proposal, Gulliver says: "A 
strange effect of narrow principles and short views! That a prince ... should from a nice, unnecessary scruple, whereas in Europe we can have no conception, lit slip an opportunity put into his hands, that would have made him absolute master of the lives, the liberties, and the fortunes of his people" (71).

In "A Voyage to the Country of the Houyhnhnms," Swift presents the fact that there is no law in this country because the people living there need no law at all. This voyage represents the complexity of European civilization traced in the savage behavior of Yahoos. Houyhnhnms perform the necessary actions of a reasonable being. They believe that "reason alone is sufficient to govern a rational creature"; lies and worse vices have no place in their behavior. What Swifts admires and what he satirizes, have been the source of controversy in many of his scholarships. Many critics envisioned that Swift develops a complex satire of radical Protestantism. At the beginning of his sojourn in Houyhnhnmland, Gulliver acknowledges a connection between Yahoo and humans, but such acknowledgement does not exceed identification: "My horror and astonishment are not to be described, when I observed, in this abominable animal, a perfect human figure," he recalls, but then confides that "I now apprehended, that I must absolutely starve, if I did not get to some of my own species" (199). He takes pains "to distinguish" himself as much as possible, "from the cursed Race of Yahoos" by concealing himself with clothing(204). Even after the embarrassing incident in which he is forced to disrobe before his Houyhnhnm Master, Gulliver resists this identification : "I owned my resemblance in every part, but could not account for their degenerate and brutal nature (206). He speculated a certain connection but was still not able to see it with conviction. Once convinced of his own Yahooness, Gulliver "turned away my face in horror and destruction of myself; and could better endure the sight of a common Yahoo, than of my own person" (243). Here, he becomes certain of the power of this conviction.

Also significant for Gulliver to find in the Houyhnhnm Master a teacher "who daily convinced me of a thousand faults in my self, whereof I had not the least perception before" (224). But Swift does not consider forcing a conviction of sin and repentance as the main goal of preaching. In "A letter to a Young Gentleman Lately Entered into Holy Orders," Swift cautions against exploiting emotions: "I do not see how this Talent of moving the Passions, can be of any great use towards directing Christian men in the Conduct of their Lives" (69). He proposes instead a simple method: "first to tell the People what is their duty, and then to convince them that it is so" (70). While he encourages self-analysis because it seeks very much "to mortify and humble a Man into a modest and low Opinion of himself" (359), he also believes and approves that such self-analysis "maketh Men less severe upon other People's Faults" (361). Houyhnhnms, Price (1984: 203) stresses, "represent the order of mind at its purest, free of its rationalistic systembuilding or of pride in intellectual constructions. Conceived in this way, it contains much that is given to humans only in the order of charity-amoral sureness and serenity, a spontaneous goodness such as is bred in men by a "daily vision of God".

From three different communities, the following two sections will discuss samples of writings of Gordimer, Hughes and Mahfouz.

\section{The Intended Present: Relevance \& Context}

\subsection{The Belonging-Betrayal Question: Relevance}

In much the same vein, how to reconcile the right with the good is central to the overlapping meanings of order. Moral order reflects ethics with obligations like having a choice, duty...etc. The sense of having a duty is fixed in the thought of a moralist -- one should be aware of the right use of making moral conception very powerful. This article aims to discuss how the mind's we can be effective through the literary writings of three pioneer writers. In this sense, the article posits here in this section the belonging-betrayal question as the subject of a comparative study of three different cultures through the creative genre of short fiction of three pioneer writers: Nadine Gordimer (1923-), Langston Hughes (1902-1967), and Naguib Mahfouz (1911-2006). Not only is it a study of race relations to the conflicting attitudes of different races living together, but it seems fruitful to feed it with the same race's conflicting attitudes of living as well.

South African Apartheid and the US racialism share a common denominator: the former demonstrates a dehumanized system of segregating blacks from whites in law, while the latter implies a fierce dislike for the black majority through political and social actions based on assumptions of white superiority. World War I had broken the ties between the individual and his society, lowering his standard of living. The Egyptian society presents varieties of conflict like the ambitions of people for the privilege of his official occupations, the bureaucrats' cares, the youth's suffering after 1067 war which generated feelings of bitterness and frustration, and the influence and the implication of economic revival for all social classes. The vision of belonging and betrayal illustrates aspects of the relationship between individual and society in view of the social commitment to a cause and the moral commitment to humanity. In essentials, this study illuminates the struggle between our present condition and what ought to be, with an attitude towards past tradition. It attempts to see how those above mentioned writers engage in a complete revolutionary action-- the dual self-conscious reaction -- in order to weed society out of its epidemic corruption and to help combat modern man's terrible sense of crisis, as reflected in the cultural identity dilemma by suggesting ways out of it.

To defend a cause sincerely is to pose ideas baldly, see things in their reality and have a deeper insight than any of one's contemporaries. One of these definitions is E.B. White's view of 'freedom" in which he never detaches real belonging from knowing that he will be "the first to have his lopped off-even before the political dandies" (Shaw, 1955: 267). The positive/negative non-belonging means a complete revolutionary descent! To recut your cloth to follow the fashion, not to be in symbiosis with the dual sense of commitment, is never positive belonging but negative-non-belonging. This finds its echo in the interdependence of the self-personal and national-upon each other. It is the lack of selfconsciousness that leads to the irresistible crisis of cultural identity. "Commitment," in a succinct statement of Martin Aims, the English novelist, "flows as hugely as the sea. What is important is the emergence of art". The greater the conscious appeal to the crisis, the better is the reality of belonging. 
Art is indispensable to the realization of life in which the two types of realism-psychological and social-mirror the works of Gordimer, Hughes and Mahfouz. The apprehension of reality in life depends on the writer's 'limited' scope of culture, vehicle of manipulation, and the response to human experience of which all cultures have one denominator like the brotherhood of man, for example. There is fidelity to both fact and truth. Henry James sees the former as fidelity to reality by means of verisimilitude and the latter as not merely functioning like fact but makes necessary the universal appeal. Robert Bone rephrases the same criterion in two terms: "immediacy" and "distance" (1958: 248-50). Both are essential to the aesthetic success of a work of art.

With no propaganda but with growing commitment to their black fervor, the white South African Gordimer and the black Harlem Renaissance Hughes have an anti-attitude, in turn, toward apartheid and racism during their lifetime career. Not only is their work against injustice, oppression and the lack of human rights, but also they yearn for the American dream of equality for all: Gordimer supports the NGOs' struggle to free themselves and Hughes, who is "cultural ambassador," says Richard Wright, for the case of the blacks", elevates the real sense of his people's dignity in wishing for them not to forever forget "their racial background". While the world-wide applause of Mahfouz epitomizes a prestigious talent steeped in mature thought. At the centre of his human message stands the individual: the human nature and the self-crisis of modern man, and the social and political problems. Believing that one's nationality is the inevitable way to internationality, he gets himself involved in the local problems so as to accurately identify what is evil to uproot and what is good to support and develop.

Applying this view to only one representative novel as a model, this is intended to trace the writer's initial thought, usually initiated first in the novel form, then followed up the short stories in order to judge properly the question of belonging and betrayal in the long and short fiction.

There are many novels which are worth discussion. Those novels are: Gordimer's July's People (1981); Hughes' Not Without Laughter (1930); and Mahfouz's Respected Sir (1975). July's People focuses on the forthcoming period in which while superiority finishes before the inevitable coming of the black state. The reversal of roles in inter-depending a white family on a black servant reflects the deeply-rooted bitter feelings of prejudice and racial superiority. Not Without Laughter depicts the conflict between the upper class and the lower class Negro life. The upper class adapts itself to the white ideals, and dislikes the traditional blues and spirituals of the Negro culture; the lower class is proud of being Negro and respects greatly its music. Naguib Mahfouz's Respected Sir pursues the career of the bureaucrat Othman Bayyumi, who lives in a world within which hypocritical manners of lip service precede man's effective qualifications in determining high chances of appointment. He is so ambitious that he longs for the death of an employee, superior to him in rank, but he atones to God instantly. The narrator states the ceaseless belief of Bayyumi that "the holy purpose of man in life is the way to glory or the realization of divinity on earth" (1975: 90). But his lifetime ambition never comes true till on his death bed.

\subsection{Mental Representations in Literary Performances: Context}

This section aims to present some of the ways the writings of three authors across geographical countries are contextually linked. This will be discussed in three main subsections: Authority and the Individual; Familial Bonds; and In Quest of Identity as Moral Belonging.

First. This section will discuss the clash between the individual voice vis-a-vis the society in the form of official authorities. There is an exposition of the superior position of the ruler and the passive submission of the ruled with the attempts of few or more individuals to change the malfunctions in society. There are opposite roles committed by individuals and the result is either the compliance of some characters known as acts of adaptation or the defiance of those who better prefer to die as lions than to live as rats, as acts of revolution. There are different types of settings like religious, psychological, ...etc. An individual who is in conflict with the rule-governed society adapts certain religious or political views. The portrayal of religious characters should judge either their sincere loyalty to a real religion or just hypocrites.

Gordimer's stories include types of characters in a state of avoidance, confirmation or an attempt to change. Not for Publications and Other Stories and Livingston's Companions depict ordinary people defying Apartheid. Something Out There reflects an extreme ability to posit the connection between the personal and the political in a divided society so full of tensions and possible disintegration. The story 'Some Monday for Sure' within Not for Publications narrates the holding of a lorry carrying explosives materials for the mines in order to be used for sedition. The certainty and danger of revolution is inevitably emphasized to reveal aspects of black terrorism in future: some perfectly ordinary day, for sure, black South Africans will free themselves and rule themselves."

Critics see Hughes as no racist in its horrible current sense, though he write exclusively of the condition of being a Negro in America. It is rare to find a literary figure like Fesse B. Simple, in the Simple series, who is as reputable as its creator, Hughes. He is the writer's tongue to comment on the Harlem: its women, war, current events, and particularly on race. He admits that the race problem is a serious business. From Simple's Uncle Sam, Simple enumerates the many problems facing him: "I was born young, black, voteless, poor, and hungry in a state where white folks did not even put Negroes on the census." In addition, he never hesitates to mirror the black shortcomings with an honest eye in order to satirically unmask the false, shallow hypocritical nature of black and white alike. The Ways of White Folk is retrospective of the 1920s of the Harlem's aspects. The stories like 'Slave on the Block', and 'Poor, Little Black Fellow' specifically present the theme of white patronage. In 'Slave' for example, the betrayal of whites through their false motto of "philanthropic" paternalism is symbolized by Mrs. Carraway, who tells Luther, her servant:"I never liked familiar Negroes", and he immediately answers "Huh! That is too bad! I never liked poor white folks."

Mahfouz textures the individual-society conflict in countless member of stories. 'Fear', in A House of Bad Honor, turns around the struggle between bullying and the courage of a policeman who wins the battle and protects common people 
from the evils of bullying. The story whose title is to give to the Sector Organization states against the government for fulfilling their ends. Crimes like killing, suicide, physical violence, bullying and others are taken into consideration. The hypocritical nature of ElAlrami's followers in a 'A Tale Without Beginning or End' is emphasised in addition to the presentation of secular ambitious men who, in other stories, support the authorities.

Second. This section will discuss the way familial bonds are bound together. The inescapable family is the business of this section to see if a character has a sense of home (attachment) or leaves it (detachment). It has seemed important to compare stories in which the central issue originates in the fact that every individual is obliged to belong to a family of one shape or another. Others establish time limits in the relationship between small children and their parents, along with the attempt of adult characters to make liberation because of their mature thinking. The problems of marriage in the husband-wife relationship will be considered in an attempt to see the suitable foundations for the goodness of the family. A smaller world of society like family motivates us to see how persistent and inevitable social and familial links are.

Gordimer has many stories which belong to the family structure with reference to the relation of white or black toward their own skin-color as a large family. This is evident in 'Six feet of the country', primarily concerned with the white South African women towards members of their own sex. A story like 'Tenants of the Last Tree house' is in touch with the world of adolescence and the children-parents failure of communication. And 'Jump', a collection of 16 stories, three of which 'The Ultimate Safari'. 'Home', and 'Journey" succeeded fully because of the writer's focus on the personal, the ordeal of human being, caught in a terrible place and at a terrible time. Of the three, 'Home' is a story of mixed marriage between a Swedish scientist and the daughter of a South African family whose political active role is clear. As a result, the mother and brother of the daughter are detained by the police. It ends with the spouse's committed loyalty to her own family in visiting them. The spouse who is unaware of her real commitment to the original blood-ties and because of his complete inability to positively identify himself, then asks herself if she was fallen in love with another person but finally realizes the truth: "Perhaps there was no lover? He saw it was true that she had left him, but it was for them, that how, the dark family of which he was not a member, her country to which he did not belong (my italics)".

Hughes has already handled themes like isolation, mulatto, and the byways of prejudice for the several forms of racism in education, housing, employment, for example, He is primarily interested in the mulatto theme because of being really estranged after 1922 from his mulatto father. The inability of black women to oppose the raping of whites led to the cultural and psychological predicament suffered by the mulatto who is still unacknowledged, tells his white father, in a poem 'Mulato' tragically: "I am your son, white man". This became the basis of three stories: Father and Son', 'Passing' within his first collection Ways of White Falks and 'American Morning' within the collection Laughing to Keep from Crying which portrays black people themselves. This leads to a sense of alienation and psychological perturbation on the psyche of the son.

Mahfouz records major aspects within Egyptian family like the appearance of suspicion between husband and wife in 'the Arena of Lasses', given in A Tale Without Beginning or End, which reveals the husband's jealousy leading, therefore, to divorce. The matrimonial infidelity is explicitly discussed in 'Robabikia' through the men-women dialogue, who intend to marry but are frank first with each other as to what they like and dislike in common:

\section{He: Ugliness and deviation}

She: Deviation? ---

He: Recklessness.

She: Is this a disease?

He: Maybe.

She: There is no woman of a forever betrayal.

(A Tale [Arabic version], 133-34)

Also, the sense of alienation is caused by the solitude of the lover as in 'Visitation' in The Tavern. And 'the Echo' reveals the children's ingratitude toward the mother/ While the ideal father-son relationship is given in 'the Paradise of Children' which emphasizes the would-be father's patience in answering the amazing mind of his daughter's questions, while the story "the World of Allah" gives a real portrayal of how significant a salary to the husband as a responsible man.

Third. This section is in quest of identity as moral belonging. The ought-to-be necessity of what the modern man is seeking -but-never-losing the hope-in finding one's identity. Prominent as a subject prone to many meanings, identity is individually seen by E.H. Erikson as a means for knowing and identifying the self, and socially seen by others for the possibility of finding a meaning for the person in his/her relations to society. To belong or not is, for sure, determined by the action and reaction followed as a result. Since a moral action depends on the infinite number of choices available to an individual through already-done behaviors and the obligations he ought to do, there is an inevitable relation between ethics and the individual's identity of belonging. Within a painful real world full of conflicts not only between individual and society, but also between members of the one family or another (sec above), the value of this section is, therefore, to focus on the variant types of moral belonging in the quest for their misdirected souls, for the moral self that stimulates them toward a conscious sensitive development of belonging in actually-performed action as an end per se. The philosophical vision finds a room in this section, too. This leads to variant stories in their hope for belonging and 
the realization of identity either through love, hope, dream, having virtues like patience ...etc as individual acts in quest of truth or through sharing experience publicly for the common good, meaning collective contact with each other.

The best of the three writers' short stories will be selected to express the ethos of this section. Gordimer seems to penetrate deeply into an understanding of her both colored and white characters. Her work is pregnant with the themes of understanding, forgiveness, and adjustment. Like Forester's A Passage to India, she records the abortive attempts of both middle-class whites and more blacks to respect the values of each other. 'Ah, woe is Me; is a tender story within The Soft Voice of the Serpent. It reveals the dilemma of a young black girl who, because of the sickness of her mother and of her father's loss of job, weeps in front of a white woman who cannot do anything for her but just giving her hand kerchief. The story 'Which Negro Era WouldThat Be?', within Selected Stories, is so successful in showing the insoluble problem of human inability to communicate. Friday's Footprint admits the moral action of Gordimer in the liberal stand against apartheid. "The Smell of Death and Flowers" in Six Feet of the Country presents a liberal while girl's hesitation to have a final commitment to the native cause. Two of the stories in Something Out There, rather, shed light on two women[one black and the other white-who give unconsciously shelter to a man on the run from the police. The black woman, Nanike, hates the power system, and the other Pat, who is a member in liberal parties, but never commits herself to acts of resistance for danger and suffering. Gordimer encircles her in the ordeal of either staying as she is or rather a different person. Also, the Jump collection is important to consider for including stories like 'Crimes of Conscience' which unmask the inhumanity of life in South Africa.

Hughes is proud of the Negro folk culture to defy the white folk culture and the implicit decisive vision of a moral encounter that will accelerate aspects of brotherhood relations in America. All what he needs is seeing some writers, he states, of both races to write about "our problems with black tongue in white cheek, or vice versa". He admits that the Simple figure helps him to fulfill. In reading the dialogue, a reader finds himself giving "lip service", a critic says, to the liberal side of the discussion but the heart shares Simple's more realistic evaluation of a given situation. For example, Simple, who blames every bad thing happened to him on race, says: "I have been caught in some kind of riffle since I been black." When the writer object in a way to illuminate the race question-and what do I see? Me (italics added)." This means that though his blackness is the problem, he is preoccupied with discovery of what it really means to be black. This is successfully applied to his outstanding achievement 'The Blues I'm playing' within The Ways of White Falks. He emphasizes the almost degradation of the pretended superiority of while culture acted by Dora Ellsworth, the protagonist by presenting her absurd judgments. A representative of the black culture is the pianist, black protege, Oceola Jones who elevates her cultural identity throughout her music by standing bravely against the cultural alienation of her patroness, who says: I[Ellsworth] must get her out of Harlem at once. I believe it's worse than Chinatown." But Oceola shows an eager belonging to live among and within her Harlem people.

Mahfouz poses varieties of subjects essential to the body of this section like the cause of freedom in 'Rave Whisper'/ The value of love, especially brotherly love, is discussed to bring up a world devoid of hatred but full of friendship, virtues, duty, responsibility, alternatives, the past's respect, and others. Most of these concepts are primarily discussed in the collection The Satan's Preaching. A story like 'Ayoub' signifies the value of work per se. Other topics like the double-sized blessing of money, and the truth of death are blended in stories to ponder. The story 'love and Mask' is liable to be tackled mainly here because of its essential significance of having religious beliefs in approaching the reality of human existence. It narrates the son's disobedience of the father, Dawood ElNadorgi's policy of bringing up. The protagonist represents the misdirected soul of those lost people who are in quest of the right direction, while the narrator in the story 'Sultan' provides us with a pivotal wisdom to the dual self-consciousness of the thesis: "Life does not lie in the beating of heart or the moving of blood but in the consciousness of people as a meaning."

\section{AGREE: a final note}

This previous discussion of four sections has developed a discussion of memory in context and its relationship to culture, history and self. Based on the discussion of two main questions, a question in perspective and the belongingbetrayal question, the fact is that any transfer from the discussion of one question of the language (and culture) in the past to another discussion of another question of the issue of culture (and language) in the present is a transfer of these three parameters (Make, Intend and Agree). This triple structural parameter of the work of art is considered the best way for my presentation of a study of the relationship between language and culture. The agreed principles influencing the actual translation transfer from one the language and culture in the past into the culture and language in the present shows the possible relevance of factors that determine each. That is, the linguistic and semiotic aspects can be well presented in view of the British linguist Halliday's Language as a Social Semiotic and the cultural and pragmatic will be finally discussed in the philosophical view of Bakhtin's the dialogic principle.

At the outset, the article refers to the reliance of the discussion on the two pivotal elements of relevance and context as given in some detail in section 4 can be attempted to investigate the individual's commitment to the whole society, then to the family, the smaller unit where it presents the moral commitment of the misdirected souls in quest of their identity. The position taken here has been to deploy the dialogic ideas of the language philosopher Mikhail Bakhtin not only to emphasize the analytical tools required to describe the dialogism of the past and the present as a liberal art of translation but also to map a new space for the art of answerability to the appropriation of (post-)colonialism, from the spectrum of outspoken engagement of the political conception going down to the conception of Engaging the Mind's Eye as a force for social change and liberation. Danow (1991:23) stresses this point by contending the following:

Essentially the same idea finds its concise formulation in the writings of the American logician and semiotician, Charles Sanders Pierce, who claims that 'thinking always proceeds in the form of a dialogue - a dialoge between different phases of the ego...' (1933: 4.60. Even more succinctly, Pierce observes: 'All thinking is dialogic in form' (1935: 6.338), a premise with which Bakhtin would surely agree. A 
special emphasis emerges, however, when Bakhtin claims that dialogic relations 'lie in the realm of discourse for discourse is by its very nature dialogic' (PDP, 183). Accordingly, dialogue is perceived as immanent to language as the basis of all human communication.

\section{References}

Bakhtin, Michael. (1994). Discourse in Life ad Discourse in Art. In Elbow.Mahwah, NJ (Ed), Landmark Essays on Voice and Writing (pp. 3-10), Hermagoras Press.

Danow, K. D. (1991). The Thought of Mikhail Bakhtin. Palgrave.

Gewaily, M. (2014). Translation and the Metaphor of Relation: Confluences of 'Answerability in IJCLTS, 2 (1), 22- 29.

Gewaily. M. (2013) Translation as Liberal Art: Four Voices in IJCLTS, 1 (3), 6-12.

Halliday, M. A. K., \& Hasan, Ruqaiya (1985). Language, Context and Text: Aspects of Language in a Social-semiotic perspective. Oxford: Oxford University Press.

Mahfouz, Naguib. المحترم حضرة Hadrat al-Muhtaram. Respected Sir (Trans. \& Introd. by Rasheed El- Enany. The American University in Cairo Press, 1966.

Munford, Clarence \& Identical, J. (1996). Race and Reparations: A Black Perspective for the 21th Century. Trento: Africa World Press.

Ong, Walter J., S.J. (1977). Interfaces of the Word. In Walter Ong (Author), Studies in the Evolution of Consciousness and Culture. Ithaca: Cornell University Press.

Price, Martin. (1984).To The Palace of Wisdom: Studies in Order and Energy from Dryden to Blake. New York: Garland Press.

Shaw, Charles B. (1955). American Essays. New York: Mentor Book.

Swift, Jonathan. (1974). Gulliver's Travels. PA: The Franklin Library. 